\title{
Bacterial contamination of Nigerian currency notes: A comparative analysis of different denominations recovered from local food vendors
}

Chigozie E Ofoedu ${ }^{\text {Corresp., }}{ }^{1}$, Jude O. Iwouno ${ }^{1}$, Ijeoma M. Agunwah ${ }^{1}$, Perpetual Z. Obodoechi ${ }^{1}$, Charles Odilichukwu R. Okpala ${ }^{\text {Corresp., } 2 \text {, Małgorzata Korzeniowska }}{ }^{2}$

\footnotetext{
1 Department of Food Science and Technology, School of Engineering and Engineering Technology, Federal University of Technology, Owerri, Imo State, Nigeria

2 Department of Functional Food Products Development, Faculty of Biotechnology and Food Science, Wroclaw University of Environmental and Life Sciences, Wroclaw, Poland
}

Corresponding Authors: Chigozie E Ofoedu, Charles Odilichukwu R. Okpala

Email address: chigozie.ofoedu@futo.edu.ng, charlesokpala@gmail.com

Microbial transmission, on the surface of any currency note, can either be through direct (hand-to-hand contact) or indirect (food or other inanimate objects) means. To ascertain the degree of bacterial load enumerated during the handling of money and food items, particularly on currency note by denominations, should be of public health importance. Despite the available literature regarding microbial contamination of Nigerian currency notes, there is still paucity of information about how microbial contamination/load differ across the denominations specific to different food vendors. In this context, therefore, the current study investigated bacterial contamination of Nigerian currency notes via a comparative study of different denominations ( $\# 1000, \# 500, \# 200, \# 100, \# 50, \# 20, \# 10$, and $\# 5$ ) recovered from local food vendors. Specifically, the different food handlers/vendors included fruit, meat, vegetable, fish, and grain/cereal sellers. All emergent data from $8 \times 5$ factorial design of experiment were of duplicate measurements. To consider the currency denominations and food vendor type, a one-factor-at-a-time analysis of variance (ANOVA) was conducted. Results showed that about $81.7 \%$ of currency notes were contaminated with either Escherichia coli, Klebsiella spp. or Staphylococcus spp. in varying degrees. The higher denominations of \#500, $\# 200$, and \#100 note, with the exception of \#1000 note, recorded increased degree of contamination over the lower denominations $\# 50, \# 20, \# 10$, and $\# 5$ note. Specifically, the \#100 currency note appeared the most contaminated $\left(1.32 \times 10^{5} \mathrm{cfu} / \mathrm{ml}\right)$ whereas $\# 5$ note appeared the least contaminated $\left(1.46 \times 10^{4} \mathrm{cfu} / \mathrm{ml}\right)$. The frequency of isolated bacteria on currency notes from vegetable, meat, and fish sellers were significantly higher $(p<0.05)$ compared to other food vendors. The degree of bacterial contamination appears dependent on the food vendor type and currency denomination(s). An increased awareness and education 
among food vendors and ready-to-eat food sellers is needed, to mitigate the possible cross-contamination between currency notes and foodstuff, as this would help consumers know more about the potential health risks such simultaneous activities do pose on food safety. <!--[if !supportLineBreakNewLine]--> <!--[endif]--> 
1 Revised for: PeerJ - Life \& Environment

2

3 Bacterial Contamination of Nigerian Currency Notes: A

4 Comparative Analysis of Different Denominations recovered

5 from Local Food Vendors

6 Chigozie E. Ofoedu ${ }^{1 *}$, Jude O. Iwouno ${ }^{1}$, Ijeoma M. Agunwah ${ }^{1}$, Perpetual Z. Obodoechi ${ }^{1}$,

7 Charles Odilichukwu R. Okpala ${ }^{2 *}$ and Małgorzata Korzeniowska²

8 'Department of Food Science and Technology, School of Engineering and Engineering

9 Technology, Federal University of Technology, Owerri, Imo State, Nigeria; ${ }^{2}$ Department

10 of Functional Food Products Development, Faculty of Biotechnology and Food Science,

11 Wroclaw University of Environmental and Life Sciences, 50-375 Wroclaw, Poland.

$12{ }^{*}$ Correspondence: chigozie.ofoedu@futo.edu.ng (CE Ofoedu);

13 charlesokpala@gmail.com (COR Okpala) 


\section{Abstract}

Microbial transmission, on the surface of any currency note, can either be through direct (hand-to-hand contact) or indirect (food or other inanimate objects) means. To ascertain the degree of bacterial load enumerated during the handling of money and food items, particularly on currency note by denominations, should be of public health importance. Despite the available literature regarding microbial contamination of Nigerian currency notes, there is still paucity of information about how microbial contamination/load differ across the denominations specific to different food vendors. In this context, therefore, the current study investigated bacterial contamination of Nigerian currency notes via a comparative study of different denominations ( $\$ 1000, \# 500, \# 200, \# 100, \# 50, \# 20, \# 10$, and $\$ 5$ ) recovered from local food vendors. Specifically, the different food handlers/vendors included fruit, meat, vegetable, fish, and grain/cereal sellers. All emergent data from $8 \times 5$ factorial design of experiment were of duplicate measurements. To consider the currency denominations and food vendor type, a one-factor-at-a-time analysis of variance (ANOVA) was conducted. Results showed that about $81.7 \%$ of currency notes were contaminated with either Escherichia coli, Klebsiella spp. or Staphylococcus spp. in varying degrees. The higher denominations of $\$ 500, \$ 200$, and $\$ 100$ note, with the exception of $\$ 1000$ note, recorded increased degree of contamination over the lower denominations $\$ 50, \approx 20$, $\# 10$, and $\$ 5$ note. Specifically, the $\$ 100$ currency note appeared the most contaminated $\left(1.32 \times 10^{5} \mathrm{cfu} / \mathrm{ml}\right)$ whereas $\$ 5$ note appeared the least contaminated $\left(1.46 \times 10^{4} \mathrm{cfu} / \mathrm{ml}\right)$. The frequency of isolated bacteria on currency notes from vegetable, meat, and fish sellers were significantly higher $(p<0.05)$ compared to other food vendors. The degree of bacterial contamination appears dependent on the food vendor type and currency denomination(s). An increased awareness and education among food vendors and ready-to-eat food sellers is needed, to mitigate the possible cross-contamination between currency notes and foodstuff, as this would help consumers know more about the potential health risks such simultaneous activities do pose on food safety.

Keywords: Bacterial contamination; currency notes; food vendors; Escherichia coli; Staphylococcus spp.; Klebsiella spp. 
Introduction

Worldwide, currency notes and money in general serve as means of economic exchange of goods and services, to defer payments and settle debts (Awe et al., 2010; Ogunleye, 2005; Okon et al., 2003). Between the late 1800s and early 1900s, scientists postulated the association of handling money with disease transmission. Subsequently, by modern scientific techniques, these postulations confirmed that pathogenic organisms can be isolated from currency/money surfaces (Alemu, 2014; Awe et al., 2010). For example, Citrobacter spp., Escherichia coli, Mycobacterium spp., Pseudomonas aeroginosa, Salmonella spp., and Staphylococcus aureus, are among the examples of foodborne pathogenic microorganisms reported on currency notes (Awe et al., 2010). By adhering to various surfaces, food pathogens such as E. coli, S. aureus and Salmonella spp. could remain viable for hours or even days of postcontamination (Okpala and Ezeonu, 2019). However, whether it is between clean and dirty hands, the movement of currency notes especially within the agrofood supply chain would never stop. This inevitable situation potentially facilitates continued occurrence of microbial contamination and proliferation between currency notes and foodstuffs even more likely (Agarwal et al., 2015; Thiruvengadam et al, 2014). To reiterate, the process of microbial contamination and more importantly, its subsequent transmission, the latter with respect to the surface of any currency note, has been understood to be of either direct (hand-to-hand contact) or indirect (food or other inanimate objects) means (Cooper, 1991).

Even though consumers can help to prevent foodborne disease incidence, the different sources from which microorganisms are able transfer to food is not new. For instance, microbial contamination takes place during the various stages of food preparation. Another instance, fruits on trees and vegetables grown on the soil are naturally microbiologically contaminated. Some cells of such microbes could still remain even after washing (Okpala and Ezeonu, 2019). Besides foodstuffs as well as drinking water that could get contaminated, there remains a wide spectrum of microbial pathogens that can contaminate animals and food products, all of which are among the fundamental causes of foodborne disease incidence and spread (Okpala et al., in- 
89 press). During the food handling processes within the agrofood supply chain, the 90 contamination of currency notes can take place, particularly involving diverse flora and 91 fauna, aerosols generated by coughing and sneezing, anal region, wounds, to the skin, 92 water, and soil (Agarwal et al., 2015; Thiruvengadam et al., 2014). Currency notes, 93 even before it would reach the bank and in the process of circulating and passing 94 through hands during daily transactions, can equally transmit the pathogenic microbes (Awodi and Nock, 2001; Yakubu, Ehiowemwenguan and Inetianbor, 2014). Besides the large surface area of any given currency note, a number of pathogenic microorganisms, not only capable of surviving on these notes but also, can serve as useful candidates of foodborne pathogens (Michaels, 2002; Podhajny, 2004) and can increase the probability of foodborne disease incidence/spread. The latter can also serve as a useful indicator of poor environmental hygiene and sanitation levels, all of which remains of great public health importance (Cooper, 1991).

Relevant literature about microbial status and survival of pathogens on currency notes have been shown by many workers in Turkey, the United States, Australia, India, Egypt, and China (Xu et al., 2005; Goktas \& Oktay, 1992; Pope et al., 2002; FSA, 2000; El-Dars \& Hassan, 2005; Singh, Thakur \& Kalpana, 2002). Other studies regarding contamination ascribed to microbial load specific to national currency notes have been reported in Bangladesh (Ahmed et al., 2010; Hosen et al., 2006), Ethiopia (Alemayehu and Ashenafi, 2019), India (Rote, Deogade and Kawale, 2010), Iran (Dehghani, Dehghani, and Estakhr, 2011), Nepal (Lamichhane et al., 2009; Prasai et al., 2008), Nigeria (Awe et al., 2010; Kawo et al., 2009; Oyero and Emikpe, 2007; Umeh et al.,

111 2007), Saudi Arabia (Ghamdi et al., 2011; Rashed et al., 2006), South Africa (Igumbor

112 et al., 2007), as well as Sudan (Saadabi et al., 2010). In Europe, Mändar et al. (2016)

113 studied microbial contamination of euro money, whereas in the USA, Michaels (2002)

114 reported on handling money and serving ready-to-eat food, which considered the same

115 gloved hands or without hygiene intervention, and provided in food service

116 establishments, would introduce the risk of cross-contamination to foods. In the global

117 front, Vriesekoop et al. (2010) performed the hygiene status of some world's currencies

118 by capturing food outlets in 10 different countries (Australia, Burkina Faso, China,

119 Ireland, Netherlands, New Zealand, Nigeria, Mexico, the United Kingdom, and the 
120 United States). By assessing the public health risks associated with the simultaneous

121 handling of food and money, Brady and Kelly (2000) showed that coagulase-positive

122 Staphylococci could be present on the currency note surfaces. The environment

123 remains a critical player in the food-related microbial transmission process to humans.

124 The environment would also compose materials that are viable candidates for the

125 (microbial) pathogens (Anderson and May, 1991; Struthers and Westran, 2003).

126 Besides currency note contamination with bacteria that bring about wide range of

127 diseases (Pope et al., 2002), how it is able exchange through hands especially within

128 the food supply chain (Agarwal et al., 2015; Thiruvengadam et al, 2014), together with

129 the poor sanitation practices that could arise in the market, restaurants and

130 slaughterhouses is likely to reflect how multi-resistant microbial strains are able to

131 cross-contaminate (Emikpe and Oyero, 2011; Oyero and Emikpe, 2007). Despite the

132 available literature about microbial contamination of Nigerian currency note (Emikpe

133 and Oyero, 2011; Enemour, Victor, and Oguntibeju, 2012; Oyero and Emikpe, 2007;

134 Umeh, Juluku, and Ichor, 2007; Uneke and Ogbu, 2007), relevant information regarding

135 how microbial contamination/load differ across the denominations is still insufficient. It is

136 reasonable to say that food handlers in Nigeria, oftentimes, after handling currency

137 notes, do fail to properly wash or sanitise their hands and other food/food-related

138 facilities. To better understand how (pathogenic) microorganisms get enumerated, and

139 subsequently circulated between foodstuffs and different currency denominations/notes,

140 should be of consumer health concern. This should be considered particularly important

141 with respect to food handlers in Nigeria who many a times have to perform financial

142 duties alongside foodstuffs. For the reason that foodstuffs would most likely differ with

143 microbial contaminants/load, however, such additional knowledge and understanding on

144 microbial enumeration as well as circulation between foodstuffs and different

145 currency denominations/notes could help, not only in identifying the actual sources of

146 the foodborne diseases, but also, in enlightening the food handlers, food traders, health

147 workers, and the general public as a whole, about the inherent (public) health risks

148 potentially associated with the currency notes, specifically when not handled in a

149 hygienic safe manner. In this context, therefore, the current study investigated the

150 bacterial contamination of Nigerian currency notes via a comparative study of different 
151 denomination notes recovered from local food vendors.

152

153 Materials \& Methods

\section{Schematic overview of experimental programme}

155 The schematic overview of the experimental programme, from the collection of currency note samples, preparation of currency note samples for microbial determinations, inoculation, incubation, to identification of different bacterial isolates, is shown in Figure 1. To reiterate, this current study was directed to investigate the bacterial contamination of Nigerian currency notes via a comparative study of different denomination notes recovered from local food vendors. Specifically, the different food handlers/vendors included fruit, meat, vegetable, fish and grain/cereal sellers. The different denominations included $\$ 1000, \$ 500, \$ 200, \$ 100, \$ 50, \$ 20$, and $\$ 5$ currency notes. For the reason that there were 5 different food handler/vendor types, and 8 different currency note denominations, a factorial design of experiment was deemed appropriate for this study, specifically $8 \times 5$ factorial type.

\section{Collection currency notes}

A total of 80 samples of Nigerian currency notes consisting of 10 pieces of eight (8) different denominations ( $\$ 1000, \$ 500, \$ 200, \$ 100, \$ 50, \$ 20, \# 10$, and $\$ 5$ ) were randomly collected from different food vendor types at Relief Market in Owerri, Imo State, Nigeria. This Relief Market is among major markets that provide the food demands of the ever increasing Owerri population, projected excess of 800,000 as of 2019 (Macrotrends, Accessed 27 Sept., 2020). Each currency denomination was aseptically collected from food vendors and placed in an ultra violet (UV) sterilized polyethylene bag and shortly after, transported to Food Microbiology laboratory of the Department of Food Science and Technology, Federal University of Technology, Owerri for bacteriological analysis. At all instances, the time period from point of collection of currency note, to arrival of laboratory did not exceed $2 \mathrm{~h}$.

\section{Preparation of materials/samples}

Ringer's solution (quarter-strength) was prepared, by dissolving one ringer's solution tablet (Merck, Darmstadt, Germany) with a composition of $2.25 \mathrm{~g} / \mathrm{L}$ sodium chloride, $0.015 \mathrm{~g} / \mathrm{L}$ potassium chloride, $0.12 \mathrm{~g} / \mathrm{L}$ calcium chloride, and $0.05 \mathrm{~g} / \mathrm{L}$ sodium 
182 bicarbonate, in $500 \mathrm{~mL}$ of distilled water. All media, diluents, glasswares, and forceps 183 used were sterilised by autoclaving at $121^{\circ} \mathrm{C}$ for $15 \mathrm{~min}$ at $15 \mathrm{psi}$, while the wire loops

184 were sterilised by flaming. Materials were allowed to cool, wrapped in an aluminum foil, 185 and stored until needed for microbiological analysis.

$186 \quad$ Upon arrival at laboratory after sample collection, each Naira note was

187 aseptically inserted into a beaker containing $100 \mathrm{~mL}$ of sterile ringer's solution, and

188 allowed to stand for $30 \mathrm{~min}$ at ambient temperature $\left(25-28^{\circ} \mathrm{C}\right)$. During this $30 \mathrm{~min}$

189 period, the beaker was gently and repeatedly shaken as it is widely believed to facilitate

190 the detachment of the adhered microbes (bacteria) from the Naira currency surface as

191 much as possible into the solution. Subsequently, the Naira note was aseptically

192 removed from the beaker using sterile forceps. Thus, the beaker content (washed liquor

193 of soaked notes) served as the resultant test sample for bacterial inoculation, so as to

194 determine the (bacterial) load as well as enumerate the type. The prepared suspensions

195 for test inoculation were used within $2 \mathrm{~h}$ to avoid the risk of cross contamination from

196 the environment.

197 Serial dilution, incubation and counting of bacterial colonies

198 Serial dilution $\left(10^{-2}\right.$ and $\left.10^{-3}\right)$ of the washed liquor of soaked notes was

199 performed. Subsequently, aliquot sample $(0.1 \mathrm{ml})$ of each was inoculated on nutrient

200 agar plates using spread plate method, and incubated at $37^{\circ} \mathrm{C}$ for $24 \mathrm{~h}$. This was

201 performed in duplicates for each currency denomination note per food vendor type. To

202 verify testing conditions, a negative control (with no test material included) was

203 performed using the chosen diluent, inoculated on nutrient agar plates and incubated at

$20437^{\circ} \mathrm{C}$ for $24 \mathrm{~h}$. The control served strictly for the validity and verification of the testing 205 conditions.

206 The colony counter (Astor 20 Colony Counter, Astori Tecnica, Italy) was used to 207 determine the colony numbers on different plates. The arithmetic mean of the counts 208 per medium were recorded, and resultant colony forming units per millilitre (cfu/ml) in 209 the original inoculum, was determined consistent with methods described previously

210 (Cheesbrough, 2000).

211 Bacterial characterisation and identification

212 The characteristic identification (and not quantification) of bacterial colonies were 
213 based on its morphology and Gram reaction, catalase and coagulase tests; biochemical

214 tests for indole production, citrate utilization, and urase activity; triple sugar iron (TSI)

215 agar tests (for glucose, lactose and sucrose fermentation); as well as hydrogen

216 sulfide/gas production tests, and oxidase tests, following the methods described

217 previously (Buller, 2014; Cheesbrough, 2000).

218 Statistical analysis

219 All emergent data from $8 \times 5$ factorial design of experiment as shown in Table 1

220 were of duplicate measurements. In order to determine the degree of bacterial load that

221 had proliferated on currency note by food vendor type, a one-factor-at-a-time ANOVA

222 was applied. The Fisher's least significant difference (LSD) was used to resolve mean

223 differences. The statistical significant difference was set at the 95\% $(p<0.05)$ confidence

224 level. The IBM SPSS software version 20 (IBM Corporation, New York, USA) was used

225 to do the data analysis.

226 (Please place Table 1 here)

227 Results

228 Table 2 shows the total viable count (TVC) of Naira denominations isolated from

229 different food vendors. The TVC on Naira denominations handled by fruit, meat,

230 vegetable, fish and grain sellers respectively ranged from $3.0 \times 10^{3}$ to $2.2 \times 10^{5} \mathrm{cfu} / \mathrm{ml}$,

231 from $3.0 \times 10^{3}$ to $1.9 \times 10^{5} \mathrm{cfu} / \mathrm{ml}$, from $3.0 \times 10^{2}$ to $1.3 \times 10^{5} \mathrm{cfu} / \mathrm{ml}$, from $1.3 \times 10^{4}$ to

$2322.9 \times 10^{5} \mathrm{cfu} / \mathrm{ml}$, and from $5.0 \times 10^{2}$ to $5.1 \times 10^{4} \mathrm{cfu} / \mathrm{ml}$. Additionally, the TVC

233 significantly differed $(p<0.05)$ across different currency notes, which ranged from $1.46 \times$

$23410^{4}$ to $1.33 \times 10^{5} \mathrm{cfu} / \mathrm{ml}$, and across different food vendors, which ranged from $8.91 \times$

$23510^{3}$ to $1.18 \times 10^{5} \mathrm{cfu} / \mathrm{ml}$ Additionally, the TVC trend across the different currency

236 denominations followed: $100\left(132.72 \times 10^{3} \mathrm{cfu} / \mathrm{ml}\right)>200\left(75.40 \times 10^{3} \mathrm{cfu} / \mathrm{ml}\right)>\$ 500$

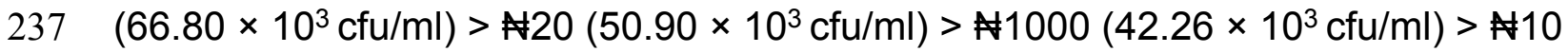

$238\left(37.40 \times 10^{3} \mathrm{cfu} / \mathrm{ml}\right)>$ \$5 $\left(14.64 \times 10^{3} \mathrm{cfu} / \mathrm{ml}\right)$.

239 (Please place Table 2 here)

240 Tables 3, 4 and 5 respectively show the Escherichia coli, Klebsiella spp. and

241 Staphylococci spp. of Naira denominations recovered from different food vendors.

242 Specifically, the $E$. coli count isolated from Naira denominations recovered from fruit,

243 meat, vegetable, fish, and grain sellers respectively ranged from $9.0 \times 10^{2}$ to $4.0 \times 10^{3}$ 
$244 \mathrm{cfu} / \mathrm{ml}$, from $7.0 \times 10^{1}$ to $6.5 \times 10^{3} \mathrm{cfu} / \mathrm{ml}$, from $2.0 \times 10^{2}$ to $6.0 \times 10^{2} \mathrm{cfu} / \mathrm{ml}$, from $1.0 \times$

$24510^{2}$ to $1.0 \times 10^{4} \mathrm{cfu} / \mathrm{ml}$, and from $2.0 \times 10^{1}$ to $8.2 \times 10^{2} \mathrm{cfu} / \mathrm{ml}$. Specifically also, the

246 Klebsiella spp. count isolated from Naira denominations recovered from fruit, meat,

247 vegetable, fish, and grain sellers respectively ranged from $2.0 \times 10^{2}$ to $8.5 \times 10^{2} \mathrm{cfu} / \mathrm{ml}$,

248 from $4.0 \times 10^{1}$ to $5.2 \times 10^{3} \mathrm{cfu} / \mathrm{ml}$, from $1.0 \times 10^{2}$ to $1.8 \times 10^{3} \mathrm{cfu} / \mathrm{ml}$, from $1.9 \times 10^{2}$ to

$2495.0 \times 10^{3} \mathrm{cfu} / \mathrm{ml}$, and from $4.0 \times 10^{1}$ to $1.1 \times 10^{2} \mathrm{cfu} / \mathrm{ml}$. Specifically also, the

250 Staphylococcus spp. count isolated from Naira denominations recovered from fruit,

251 meat, vegetable, fish and grain sellers respectively ranged from $3.0 \times 10^{2}$ to $3.7 \times 10^{3}$

$252 \mathrm{cfu} / \mathrm{ml}$, from $1.1 \times 10^{2}$ to $3.7 \times 10^{3} \mathrm{cfu} / \mathrm{ml}$, from $7.0 \times 10^{1}$ to $6.0 \times 10^{3} \mathrm{cfu} / \mathrm{ml}$, from $1.5 \times$

$25310^{2}$ to $6.0 \times 10^{3} \mathrm{cfu} / \mathrm{ml}$, and from $4.0 \times 10^{1}$ to $1.6 \times 10^{3} \mathrm{cfu} / \mathrm{ml}$.

254 (Please place Tables 3, 4, and 5 here)

255

The mean values of E. coli, Klebsiella spp., and Staphylococci spp. counts

256 isolated from Naira denominations, with emphasis on the different food vendors, is

257 shown in Figure 2. The results indicate that, specific to E. coli, Klebsiella spp., and

258 Staphylococci spp., the Naira denominations recovered from grain sellers obtained less

259 bacterial contaminants, whereas those recovered from meat and fish sellers obtained

260 more bacterial contaminants. Mean values of E. coli, Klebsiella spp. and Staphylococci

261 spp. counts isolated, with emphasis on the Naira denominations recovered from

262 different food vendors, is shown in Figure 3. The results indicate that the $\$ 100$ and

263 200 specifically obtained higher E. coli and Staphylococci spp. respectively, whereas

$264 \$ 500$ obtained higher Klebsiella spp. and Staphylococci spp., although not significantly

265 different $(P>0.05)$. However, the Naira denominations with the least isolated bacterial

266 contaminants appears to be $\$ 10$ and $\# 5$ (specific to specific to Klebsiella spp.), $\$ 5$

267 (specific to Staphylococci spp.), and $\$ 1000$ (specific to E. coli).

268 (Please place Figures $\mathbf{2}$ and $\mathbf{3}$ here)

269 The prevalence of E. coli, Klebsiella spp. and Staphylococci spp. on Naira

270 denominations recovered from different food vendors is shown in Table 6. Regardless

271 of food vendors, $81.7 \%$ of Naira denominations recovered had been contaminated by at

272 least one of the determined bacteria, and in the following prevalence trend: E. coli

$273(87.5 \%)>$ Staphylococci spp. $(85 \%)>$ Klebsiella spp. (72.5\%). Besides, the total

274 prevalence of bacterial load of Naira denominations, specific to how it was recovered 
275 from food vendors, followed this trend: vegetable sellers $(91.7 \%)>$ meat sellers $(87.5 \%)$

$276>$ fish sellers $(87.5 \%)>$ fruit sellers $(75 \%)>$ grain sellers $(66.7 \%)$.

277 (Please place Table 6 here)

278

279

280 Discussion

281 The TVC on Naira denominations clearly obtained varying ranges across food

282 vendors. The 100 currency denomination obtained the highest TVC $\left(1.32 \times 10^{5}\right.$

$283 \mathrm{cfu} / \mathrm{ml}$ ), which is consistent with the report of Kawo et al.(2009), attributable to its

284 frequent as well as high usage in today's Nigeria and across her society's daily

285 transactions (Adamu et al., 2012; Umeh et al., 2007). On the other hand, the $\$ 5$

286 currency denomination obtained the least TVC $\left(1.46 \times 10^{4} \mathrm{cfu} / \mathrm{ml}\right)$, probably attributable

287 to its limited use, considering that in recent times, it is hard to find any commodities sold

288 for $\$ 5$ in Nigeria. Overall, about $95 \%$ of higher denominations ( $\$ 1000, \# 500, \approx 200$, and

$289 \$ 100$ ) appeared more contaminated compared to $85 \%$ of lower denominations ( $\$ 50$,

$290 \quad 20$, 10 and $\# 5$ ), resembling the observation of previous workers (Adamu et al.,

291 2012).

292

293

The fact that $E$. coli could be isolated, as shown in Table 3, from low level of 2.0 $\times 10^{1} \mathrm{cfu} / \mathrm{ml}$ as found in $\$ 500, \$ 100$, and $\$ 5$ denominations of grain sellers, to as high

294 level of $1.0 \times 10^{4} \mathrm{cfu} / \mathrm{ml}$ as found in $\$ 100$ denomination of fish sellers, might be suggestive of the poor hygienic practices and sanitary condition exercised by these different food vendors, particularly in the handling of the Nigerian currency notes. It is possible that bacterial coliforms could find its way to the surface of the currency notes through other means apart from the food stuffs. For the currency notes to pass through the diverse environments could make it emerge a reservoir, capturing various bacteria including pathogenic $E$. coli, considered capable of surviving several days on inert surfaces (Pomperayer and Gaylarde, 2000). In addition, the currency notes if poorly handled may result in contamination of foodstuffs (and ready-to-eat foods), unless good hygienic practices (GHPs) are exercised (Barro, et al., 2006). Nonetheless, the E. coli remains an important member of Enterobacteriaceace known to bring about food infections and poisoning (Awe et al., 2010). Some E. coli strains can be associated with 
306 heat stable enterotoxin production (WHO, 1984; Jensen et al., 1997).

307

308

309

310

311

312

313

314

315

316

317

318

319

320

321

322

323

324

325

326

327

328

329

330

331

332

333

334

335

336

As shown in Table 4, the fact that Klebsiella spp. could also be isolated from Naira denominations from food vendors, from low level of $4.0 \times 10^{1} \mathrm{cfu} / \mathrm{ml}$ as found in $\# 500$ and $\# 20$ denominations of the grain sellers, to as high level of $5.2 \times 10^{3} \mathrm{cfu} / \mathrm{ml}$ as found in 200 denomination of the meat sellers, should not be too surprising, given that this specific bacteria is also an Enterobacteriaceace member. Just like E. coli, Klebsiella spp. can contaminate the water used in moistening the fingers while counting money or cross-contamination from offals. As a rod shaped Gram-negative bacteria, Klebsiella spp. could be found on the skin, mouth, intestinal lining, and could associate with urinary tract infections (Prescott et al., 2008). High rates of Klebseilla spp. on some currency notes is not new, as it has been reported in the United States coins and dollar bills (Gadsby, 1998). However, the degree to which currency notes get contaminated with Klebseilla spp. should not be underestimated. Thus, the bacterial contamination of currency notes are not only confined to developing nations.

Staphylococcus spp., a gram-positive bacteria of spherical shape is among common contaminants isolated from currency notes (Xu et al., 2005). In this current study, the rate at which Staphylococcus spp. would be found on the Naira denominations, could be attributed to such factors as contamination between normal skin(hands, fingers, faces) flora, nasal discharge, soil as well as ubiquitous distribution in the environment (Igumbor et al., 2007; Kumar et al., 2009; Larkin et al., 2009). Additionally, the rubbing off or maybe surfing from a skin flake could facilitate the occurrence of Staphylococcus spp. on the currency notes (Ahmed et al., 2010). Among Staphylococcus spp., for example, S. aureus has the capacity to secrete toxins such as pyrogenic toxin and super antigens, which can bring about health issues like food poisoning as well as toxic shock syndrome (Ayopo, 2010). Given that S. aureus could flourish in the human nose, throat, and skin, the recontamination of currency notes can occur especially during inadequate hygiene, adding cross-contamination from between currency notes and foodstuffs.

The association of E. coli, Klebsiella spp. and Staphylococci spp. of the current work would differ when emphasis is either given to different food vendors or Naira denominations, as respectively demonstrated in Figures 2 and 3 . When emphasis is 
337 given to the different food vendors (Refer to Figure 2), higher E. coli and Staphylococci

338 spp. loads were respectively found on Naira denominations recovered from the meat

339 and fish sellers. This occurrence might reflect the nature of foodstuffs dealt by these

340 vendors. High moisture content, blood, and intestinal components in both fish and meat

341 samples have the capacity to provide a sufficient reservoir for various degrees of

342 bacterial proliferation. When emphasis is given to the Naira denominations recovered

343 from different food vendors (Refer to Figure 3), the $\$ 100$ and $\$ 200$ obtained higher $E$.

344 coli and Staphylococci spp. respectively, whereas $\$ 500$ had higher Klebsiella spp. and

345 Staphylococci spp., with the least isolated bacterial contaminants at 10 and $\$ 5$

346 (Klebsiella spp.), $\$ 5$ (Staphylococci spp.), and $\$ 1000$ (E. coli). The increasing TVC

347 trend across Naira denominations $\$ 100, \$ 200$ and $\$ 500$ in Table 2, can be seen to

348 corroborate the data presented in Figure 3, which are respectively loaded with E. coli,

349 Klebsiella spp. and Staphylococci spp., attributable to the frequency of its usage in

350 daily/various food market transactions. In addition, the 1000 currency note appeared

351 the least (bacterial) contaminated, probably because it is least used in Nigeria's daily

352 foodstuffs transactions. This same reason apply to $\$ 5$, which also appeared the least

353 (bacterial) contaminated, as shown in Table 2, which also corroborated the data

354 presented in Figure 3, consistent with the least Klebsiella spp. and Staphylococci spp.,

355 and a low E. coli count, after 1000 note. Previous researchers have shown that the

356 improper handling of currency money by food vendors can transfer bacteria from

357 currency notes to humans (Michaels, 2002; Lamichhane et al., 2009). For the reason

358 that the higher denomination notes obtained greater bacterial contaminants, with the

359 exception of 1000 , authors of current work opine that the Naira denominations might

360 associate with the degree of (bacterial) contamination, resembling the argument Uneke

361 and Ogbu (2007) has made on this matter.

362 The prevalence of E. coli, Klebsiella spp. and Staphylococci spp. on currency

363 notes from different food vendors suggested the following trend: E. coli $(87.5 \%)>$

364 Staphylococci spp. (85\%) > Klebsiella spp. (72.5\%). Different from the current study, the

365 findings of Yazah et al. (2012) reported much less data frequency with different trend of

366 S. aureus $(22.5 \%)>$ E. coli $(12.5 \%)>$ Klebsiella spp. $(5 \%)$ on the Naira currency notes.

367 Based on the different food vendors, the prevalence showed the following trend: 
368 vegetable sellers $(91.7 \%)>$ meat sellers $(87.5 \%)>$ fish sellers $(87.5 \%)>$ fruit sellers

$369(75 \%)>$ grain sellers $(66.7 \%)$. Similar bacterial contamination observations involving the

370 Nigerian currency notes recovered from fish, meat and vegetable sellers have been

371 shown in previous studies (Ahmed et al., 2010; Barua et al., 2019). Applicable to other

372 countries, the Nigerian currency notes when handled in an unhygienic manner would

373 most likely supplement the frequency of bacterial contamination. This situation can arise

374 from various sources such as atmosphere (air), body of handlers (hand, skin, wounds,

375 etc), counting machine, storage environment, soil, etc (Awodi and Nock, 2001; Prasai et

376 al., 2008). Additionally, tongue-wetting of fingers appears a habit of many when

377 counting money, which could serve as means of contaminating currency notes, fingers

378 (Igumbor, et al., 2007) as well as foodstuffs. For emphasis, the simultaneous handling

379 activity between foodstuffs/food items and currency notes continues to serve as strong

380 candidates capable of promoting as well as progressing foodborne disease incidence

381 and spread through contamination and cross-contamination.

382

383 Conclusions

384 The bacterial contamination of Nigerian currency notes via a comparative study

385 of different denomination notes recovered from local food handlers/vendors has been

386 successfully investigated. Results showed about $81.7 \%$ of currency notes were

387 contaminated with either E. coli, Klebsiella spp. or Staphylococcus spp., and in varying

388 degrees. With the exception of 1000 note, the (other) higher denominations of $\$ 500$,

$389 \$ 200$, and $\$ 100$ note recorded increased degree of contamination over the lower

390 denominations of $\$ 50, \cdots 20, \$ 10$, and $\$ 5$ note. Naira denominations note from meat,

391 fish, and vegetable sellers obtained higher level of bacterial contaminants compared to

392 those of the other food vendors.

393 Increased awareness and education among food vendors and ready-to-eat food

394 sellers is warranted if possible cross-contamination between currency notes and

395 foodstuff is to be mitigated. The Central Bank of Nigeria (applicable to central banks at

396 other countries) would have to increase the robustness of the existing retrieval system,

397 if the bacterial contamination and re-contamination of Naira denominations are to be

398 reduced. This would specifically help to ensure that such highly used higher 
399

400

401

402

403

404

405

406

407

408

409

410

411

412

413

414

415

416

417

418

419

420

421

422

423

denominations of $\$ 500, \$ 200$, and $\$ 100$ note, as reported in this current study, do not remain in the circulation process for too long. Additionally, this current study contributes to the call for increased awareness at the local, state and federal government levels in Nigeria, to place more emphasis on the potential public health risks that can potentially arise from the simultaneous handling of money and foodstuffs.

There is the possibility that nutrient agar used in the current study could be limiting the colony richness of some specific bacteria over others on the spread plate. Hence, in order to enhance the richness of colony on the spread plate, considering more bacterial specific agar for use is very needful in future studies involving same and or other currency notes versus similar (to current study) or other food vendors. Another direction of future studies could be the use of 16s rRNA sequencing as well as matrix-assisted laser desorption and ionisation (MALDI), which are among promising molecular level microbiological techniques. These techniques can help increase the accuracy of bacterial identification when applied to studies investigating same (as well as other) currency notes versus same (as well as other) food vendors. It is also recommended that future studies could determine the prevalence of other microorganisms like yeast, fungi, and virus on currency notes across various food vendors, in and or by comparing different locations.

\section{References}

Adamu, J.Z., Jairus, Y. and Ameh, J.A. (2012). Bacterial Contaminants of Nigerian currency notes and associated risk factors. Research Journals of Medical Sciences 6(1): 1-6.

Agarwal, G., Ingle, N.A., Kaur, N., Ingle, E., and Charania, Z. (2015). Assessment of Microbial Contamination of Indian Currency Notes in Mathura City, India: A Cross-sectional Study. Journal of Advanced Oral Research 6(3): 43-48.

Alemayehu, H., and Ashenafi, M. (2019). Microbial load of Ethiopian currency notes collected from various sources. International Journal of Advanced Research in Biological Sciences 6(4): 119-126. DOI: http://dx.doi.org/10.22192/ijarbs.2019.06.04.016 
429 Alemu, A. (2014). Microbial Contamination of Currency Notes and Coins in Circulation: A Potential Public Health Hazard. Biomedicine and Biotechnology 2(3): 46-53.

431

432

433

434

435

436

437

438

439

440

441

442

444 445

446

447

448

449

450

451

452 453

Ahmed, S., Parveen, S., Nasreen, T., \& Feroza, B. (2010). Evaluation of the Microbial Contamination of Bangladesh Paper Currency Notes (Taka) In Circulation. Advances in Biological Research, 4 (5), 266-271.

Anderson, R.M. and May, R.M. (1991). Infectious diseases of humans, dynamics and control. Oxford University Press, New York, USA.

Awe, S., Eniola, K.I.T., Ojo, F.T. and Sani, A. (2010). Bacteriological quality of some Nigerian currencies in circulation. African Journal of Microbiological Research. 4(21): 2231-2234.

Awodi N.O, and Nock, I.H. (2001). Prevalence and Public Health Significance of Parasitic Cysts and Eggs on the Nigerian Currency. Nigerian Journal of Parasitology. 22(1\&2):137-142.

Ayopo, O.S. (2010). Isolation and Identification of pathogenic bacteria associated with circulating Naira notes in the Abeokuta Metropolis. Unpublished Thesis.

Barro, N., Bello, A.R., Savadogo, A., Ouattara, C.A.T., Liboudo, A.J., and Traoré, A.S. (2006). Hygienic status assessment of dish washing waters, utensils, hands and pieces of money from street food processing sites in Ouagadougou, Burkina Faso. African Journal of Biotechnology 5 (11):1107-1112. ISSN: 1684-5135

Barua, N., Sabuj, A.A., Haque, Z.F., Das, M., Hossain, M.T. and Saha, S. (2019). Survey of bacterial contamination and antibiotic resistance pattern of Bangladeshi paper currency notes in Mymensingh city. African Journal of Microbiology Research, 13(10): 206-213.

Brady, D.H. and Kelly M.O. (2000). Pathogens Associated with Currencies. Retrospective Study of Private Diagnostic Laboratories, University Press, Australia pp: 74 
455 Buller, N.B. (2014) Bacteria and Fungi from Fish and Other Aquatic Animals. A

456

457

458

459

460

461

462 463

464

465

466

467

468

469

470

471

472

473

474

475

476

477

478

479

480

481

Practical Identification Manual (2nd Edition), Oxfordshire, UK: CABI International Publishers, pp. 920, ISBN-13: 9781845938055.

Cheesbrough, M. (2000). District laboratory practice in tropical countries, Part 2. Cambridge University Press, Cambridge, UK.

Cooper, A.D. (1999). District Laboratory Practices in Tropical Countries. Microbiology (ELBS) Butterworths Kent, UK; pp 30-31.

Dehghani, M., Dehghani, V., and Estakhr, J. (2011). Survey of microbial contamination of Iranian currency papers. Research Journal of Pharmacy, Biological and Chemical Sciences 2: 242-248.

El-Dars, F.M. and Hassan, W.M. (2005). A preliminary bacterial study of Egyptian paper money. International Journal of Environmental Health Research 15(3): 235-239.

Emikpe, B.O. and Oyero O.G., (2011). Preliminary Investigation on the Microbial Contamination of Nigerian Currency. International Journal of Tropical Medicine.2:29-32.

Enemour, S., Victor, P.I., and Oguntibeju, O.O. (2012). Microbial contamination of currency counting machines and counting room environment in selected commercial banks. Scientific Research and Essays 7(14): 1508-1511.

Food Science Australia (FSA), (2000). Money handling in food service operations. Food Safety and Hygiene. A bulletin for the Australian Food Industry.

Gadsby, P., (1998). Filthy lucre: bugs, drugs and grime hitch a ride on the back of every buck. Discovery, 19: 76-84genes in Staphylococcus aureus isolated from paper currency. International Journal of Infectious Disease 13:450-455.

Ghamdi, A., Abdelmalek, S., Bamaga, M., Azhar, E., Wakid, M., and Alsaied, Z. (2011). Bacterial contamination of Saudi one riyal paper notes. Southeast Asian Journal of tropical Medicine and Public Health 42(3): 711-716. 
482 Goktas, P. and Oktary, G., (1992). Bacteriological examination of paper money. 483 Mikrobiyol. Bull., 26: 344-348.

484 Hosen, M., Sarif, D., Rahman, M., and Azad, A. (2006). Contamination of coliforms in 485 different paper currency notes of Bangladesh. Pakistan Journal of Biological 486 Sciences 9: 868-870.

487 Igumbor, E.O., Obi, C.L., Bessong, N.P., Potgieter, N., and Mkasi, T.C., (2007).

488 Microbiological analysis of banknotes circulating in the Venda region of Limpopo 489 Province, South Africa. South African Journal of Science 103: 365-366.

490 Jensen, M.M., Wright, D.N. and Robison, R.A. (1997). Microbiology for the Health 491 Sciences (4th Edition). Prentice Hall Publishers, pp. 530, ISBN: 978$492 \quad 0132514644$.

493 494 495

496

497

498

499 500

501

502

503

504

505 506 507

Kawo, A., Ladam, M., Labdullahi, B., and Sani, N. (2009). Prevalence and public health implications of the microbial load of abused Naira notes. Bayero Journal of Pure Applied Sciences 2: 52-57.

Kumar, J.D., Negi, Y.K., Gaur, A. and Khanna, D. (2009). Detection of virulence genes in Staphylococcus aureus isolated from paper currency. International Journal of Infectious Diseases 13 (6): e450-e455.

Larkin, E.A., Carman, R.J., Krakauer, T. and Stiles, B.G. (2009). Staphylococcus aureus: the toxic presence of a pathogen extraordinaire. Current Medicinal Chemistry 16(30): 4003-4019.

Lamichhane, J., Adhikary, S., Gautam, P., Gautam, P., Maharjan, R.,and Dhakal, B. (2009). Risk of handling paper currency in circulation chances of potential bacterial transmittance. Nepal Journal of Science and Technology, 10:161-166.

MacroTrends, Owerri, Nigeria Metro Area Population 1950-2020, https://www.macrotrends.net/cities/22015/owerri/population, Accessed 23 September 2020. 
508 Mändar, K., Sõber, T., Kõljalg, S., Rööp, T., Mändar, R., and Sepp, E. (2016).

509 Microbiological contamination of euro currency in Estonia. Journal of Infectious Diseases 48(10): 772-774.

511 Michaels, B. (2002). Handling and serving ready to eat food. Food Service Microbial

512 Contamination of Bangladesh Paper Currency Notes (Taka) in Circulation. Advances in Biological Research 4(5): 266-271.

514 Ogunleye, A.G. (2005). Macroeconomics: An introductory test. Emmaon Educational Publisher, One Ado, Ibadan, Nigeria. pp. 1-22.

Okpala, C.O.R., and Ezeonu, I.M. (2019). Food Hygiene/Microbiological Safety in the Typical Household Kitchen: Some Basic 'Must Knows' for the General Public. Journal of Pure and Applied Microbiology 13(2): 697-713.

Okpala, C.O.R., Anyanwu, M.U., Łukańko, S., Nwobi, O.C., and Korzeniowska, M. (Inpress). Some Animal-Food-Human Antimicrobial Resistance (AMR) Fundamentals, Prevention Pathways, and Global Surveillance Trends: A Terse Review. Applied Food Biotechnology (ISSN: 2345-5357).

Okon, A.I., Akinloye, O., Okoh, O.M., and Oladipo, A.A. (2003). The microbiological quality and heavy metal regimes of some dirty currency notes found in a typical Nigerian community. Science Focus 4: 116-119.

Oyero, O.G., and Emikwe, B.O. (2007). Preliminary investigation on the microbial contamination of Nigeria currency. International Journal Tropical Medicine 2(2): 29-32.

Podhajny, M.R. (2004). Paper Currency as a Breeding ground for Pathogens. Southern Medical Journal. 94(4): 365-369.

Pomperayer, R.M.D.C. and Gaylarde, C.C. (2000). The influence of temperature on the adhesion of mixed culture of Staphylococcus aureus and Escherichia coli to propylene. Food Microbiology 17: 361-365. 
534 Pope. T.W., Ender, P.T., Woelk, W.K., Koroscil, M.A. and Koroscil, T.M. (2002). Bacterial contamination of paper currency. Southern Med. J. 95: 1406-1410.

536 Prasai, T., Yami, K.D. and Joshi, D.R. (2008). Microbial load on paper/polymer currency and coins. Nepal Journal of Science and Technology 9: 105-109.

Prescott, M., Harley, P. and Klein, A. (2008). Microbiology $7^{\text {th }}$ edition. McGraw-Hill, New York, USA. Pp.124-126.

Rashed, T., Ghanas, J., Ghazvini, K., and Rashed, E. (2006). Bacterial contamination of current bank notes and coins. Medical Journal Tabriz University of Medical Sciences 28(2): 67-69.

Rote, R., Deogade, N., and Kawale, M. (2010). Isolation, characterization and antibiotic sensitivity of organism from Indian currency. Asiatic Journal of Biotechnology Resources 3: 255-260.

Saadabi, A.M., Ali, L.F., Omer, A.B., Ahmed, G.A., and Asa, R.K.A. (2010). Isolation and identification of pathogenic bacteria and fungi from some Sudanese banknote currency. Research Journal of Medical Sciences 4: 315-318.

Singh, A.Y., Thakur, B.A, Kalpana R.E. and Gog, (2002). Isolation of various Contaminants on Currency. Medical Microbiology, third edition, Mosby Publishers. pp: 186.

Struthers, J.K. and Westran, R.P. (2003). Clinical bacteriology. ASM Press, Washington DC, USA.

Thiruvengadam S., Shreenidhi K.S., Vidhyalakshmi H., Ramya M., Kamala T., and Currencies under Circulation and Identifying the Virulence Gene in Chennai (TN). Chem Tech Res. 6(9): 4108-14. 
558 Umeh, E. U., Juluku, J. U. and Ichor, T., (2007). Microbial contamination of 'Naira'

559

560

561 Uneke, C. J.,and Ogbu, O. (2007). Potential for parasite and bacterial transmission by (Nigerian Currency) notes in circulation. Research Journal of Environmental Sciences 1: 336-339. paper currency in Nigeria. Journal of Environmental Health, 69 (9): 54-60.

563

564

565

566

567

568

569

570

571

572

573

574

575

576

Vriesekoop F., Russell C., Alvarez-Mayorga B., Aidoo K., Yuan Q. and Scannell A., (2010). Dirty money: an investigation into the hygiene status of some of the world's currencies as obtained from food outlets. Foodborne Pathogens and Disease, 7 (12): 1497-502.

WHO (1984). World Health Organization. Guidelines for drinking water I with circulating naira notes in the Abeokuta Metropolis. Thesis Project, Department of Microbiology, College of Natural Sciences, University of Agriculture, Abeokuta, Ogun State. Pp 20.

Xu, J., Moore, J.E. and Millar, B.C. (2005). Ribosomal DNA (rDNA) identification of the cultural bacterial flora on monetary coinage from 17 currencies. Journal of Environmental Health 67(7): 51-55.

Yakubu, J.M., Ehiowemwenguan, G. and Inetianbor, J.E. (2014). Microorganisms Associated With Mutilated Naira Notes In Benin-City, Nigeria. International Journal of Basic and Applied Science.3:9-15. 
Figure 1

The schematic overview of the experimental programme, from the collection of currency note/paper samples, preparation of currency note samples for microbial determinations, inoculation, incubation to identification of different bacterial isolate

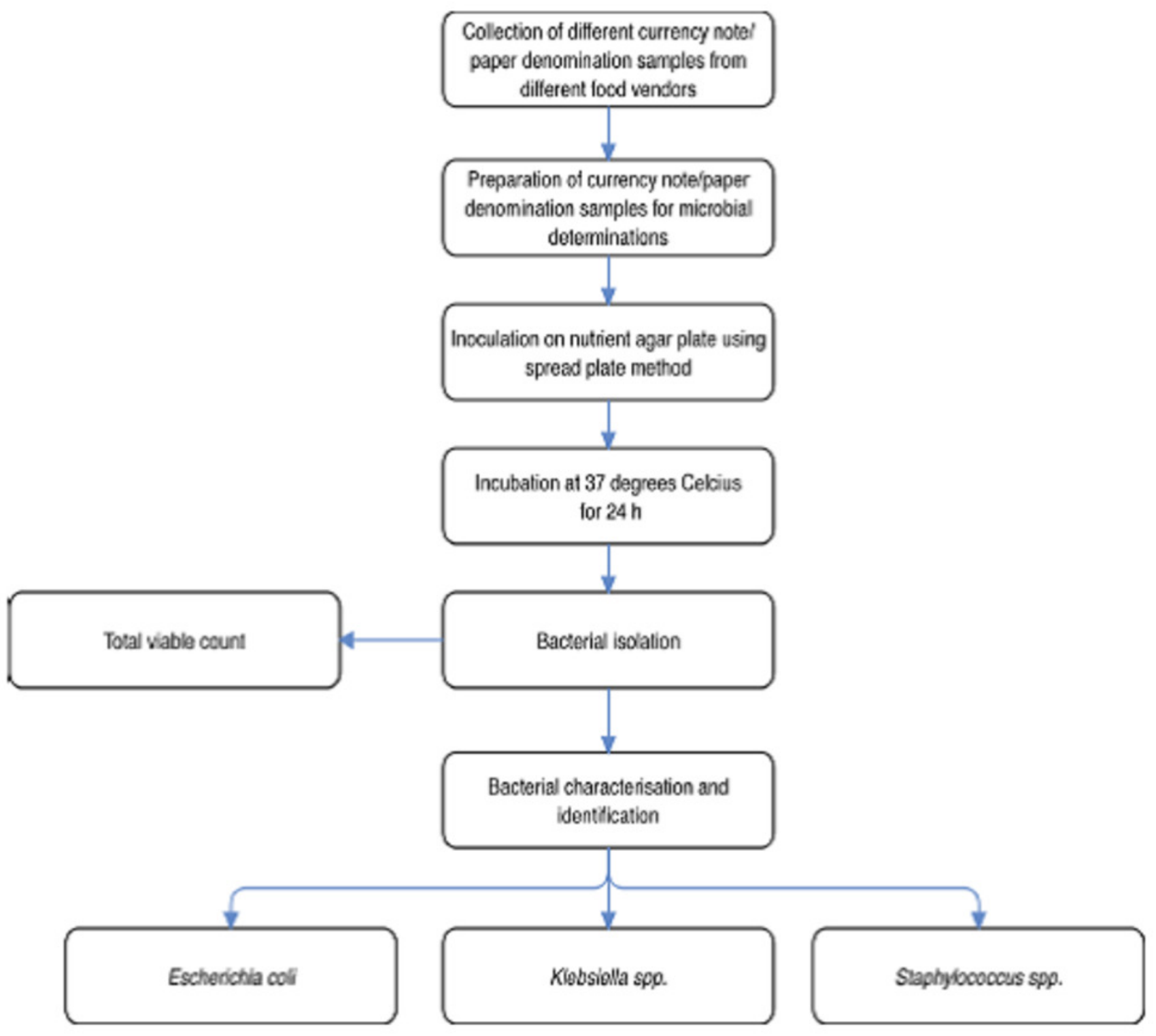




\section{Figure 2}

Mean values of E. coli, Klebsiella and Staphylococcus count isolated from Naira denominations, with emphasis on the different food vendors

(Blue colour) E. coli.

(Orange colour) Klebsiella.

(Grey colour) Staphylococci.

2.5

2

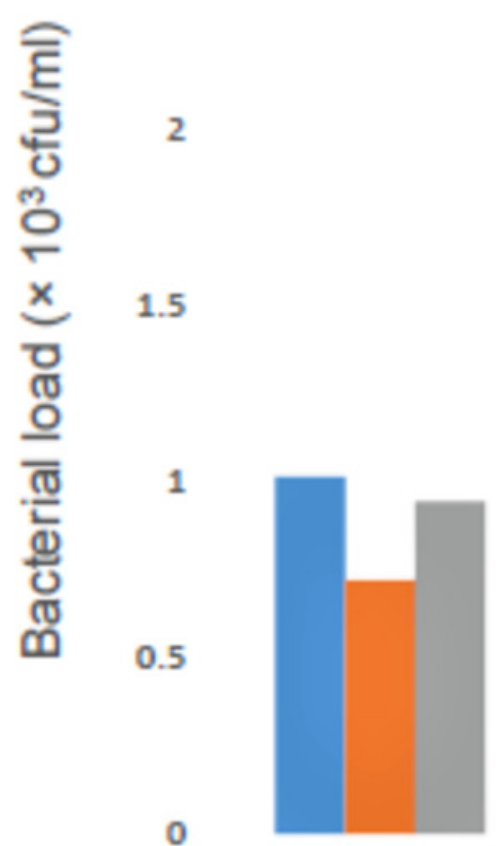

Fruit seller

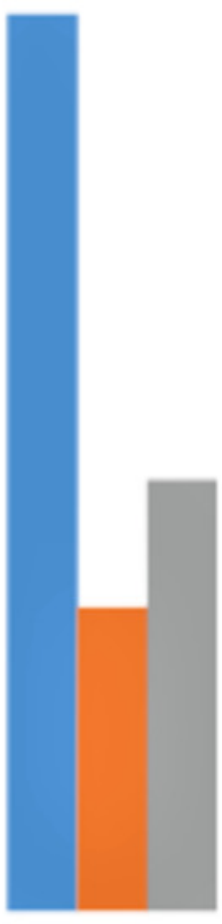

Meat seller

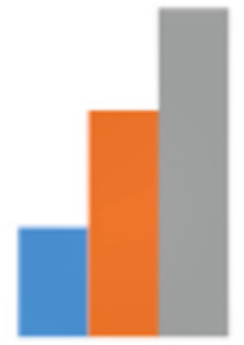

Vegetable seller

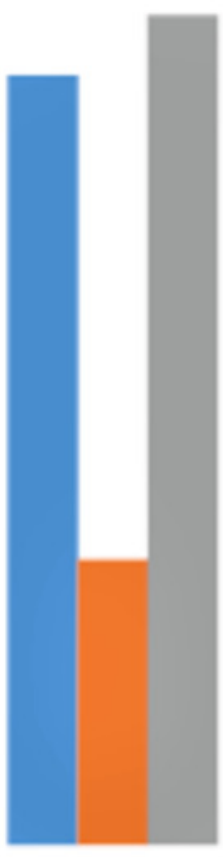

Fish seller

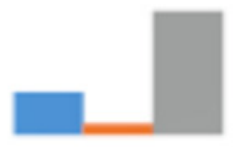

Grain seller

Food vendors 
Figure 3

Mean values of E. coli, Klebsiella and Staphylococcus count isolated, with emphasis on the Naira denominations recovered from different food vendors

(Blue colour) E. coli.

(Orange colour) Klebsiella.

(Grey colour) Staphylococci.

4

3.5

3

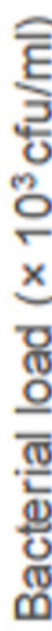

2.5

2

1.5

1

0.5

0
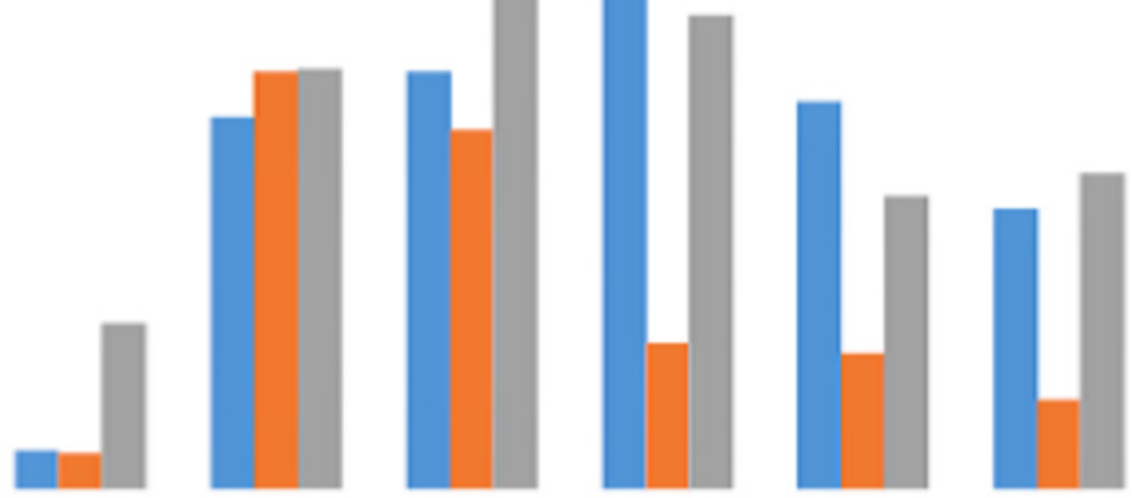

$\$ 1000$

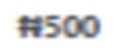

\#200

\#100

*50

$\# 20$

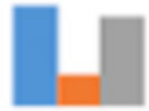

\$10

\#5

Food vendors 
Table $\mathbf{1}$ (on next page)

Table 1: Factorial experimental design table 
1 Table 1: Factorial experimental design table

\begin{tabular}{ccc}
\hline & Factor A & Factor B \\
\hline Name & $\begin{array}{c}\text { Currency } \\
\text { denomination } \\
\text { Levels }\end{array}$ & Food vendor type \\
$\mathbf{1}$ & 8 & Nominal \\
$\mathbf{2}$ & $\$ 1000$ & 5 \\
$\mathbf{3}$ & $\$ 500$ & Fruit seller \\
$\mathbf{4}$ & Meat seller \\
$\mathbf{5}$ & $\$ 100$ & Vegetable seller \\
$\mathbf{6}$ & $\$ 50$ & Fish seller \\
$\mathbf{7}$ & $\$ 20$ & Grain seller \\
$\mathbf{8}$ & $\$ 10$ & - \\
\hline
\end{tabular}


Table 2 (on next page)

Total viable count (cfu/ml) of Naira denominations recovered from different food vendors 
1 Table 2: Total viable count (cfu/ml) of Naira denominations recovered from

2 different food vendors

\begin{tabular}{lllllll}
\hline $\begin{array}{l}\text { Currency } \\
\text { denomination }\end{array}$ & $\begin{array}{l}\text { Fruit } \\
\text { sellers }\end{array}$ & $\begin{array}{l}\text { Meat } \\
\text { sellers }\end{array}$ & $\begin{array}{l}\text { Vood vendor type } \\
\text { sellers }\end{array}$ & $\begin{array}{l}\text { Fish } \\
\text { sellers }\end{array}$ & $\begin{array}{l}\text { Grain } \\
\text { sellers }\end{array}$ & Mean $\times 10^{3}$ \\
\hline \#1000 & $1.3 \times 10^{5}$ & $3.9 \times 10^{4}$ & $3.0 \times 10^{2}$ & $3.0 \times 10^{4}$ & $1.2 \times 10^{4}$ & 42.26 \\
\#500 & $9.0 \times 10^{3}$ & $7.5 \times 10^{4}$ & $1.3 \times 10^{5}$ & $1.2 \times 10^{5}$ & NGD & 66.80 \\
\#200 & $3.0 \times 10^{4}$ & $3.0 \times 10^{3}$ & $3.0 \times 10^{3}$ & $2.9 \times 10^{5}$ & $5.1 \times 10^{4}$ & 75.40 \\
\#100 & $2.2 \times 10^{5}$ & $1.4 \times 10^{5}$ & $5.0 \times 10^{4}$ & $2.5 \times 10^{5}$ & $3.6 \times 10^{3}$ & 132.72 \\
\#50 & $8.0 \times 10^{3}$ & $1.6 \times 10^{5}$ & $7.0 \times 10^{3}$ & $1.4 \times 10^{5}$ & NGD & 63.00 \\
\#20 & $1.4 \times 10^{4}$ & $1.9 \times 10^{5}$ & $2.0 \times 10^{4}$ & $3.0 \times 10^{4}$ & $5.0 \times 10^{2}$ & 50.90 \\
\#10 & $3.0 \times 10^{3}$ & $8.6 \times 10^{4}$ & $2.8 \times 10^{4}$ & $7.0 \times 10^{4}$ & NGD & 37.40 \\
\#5 & NGD & $2.9 \times 10^{4}$ & $2.7 \times 10^{4}$ & $1.3 \times 10^{4}$ & $4.2 \times 10^{3}$ & 14.64 \\
Mean $\times 10^{3}$ & 51.75 & 90.25 & 33.16 & 117.88 & 8.91 & \\
\hline Nat & & & & &
\end{tabular}

3 Values are the means of duplicate determinations

$4 \quad \mathrm{NGD}=$ No Growth Detected

5

6 


\section{Table 3 (on next page)}

Escherichia coli count (cfu/ml) of Naira denominations recovered from different food vendors 
1 Table 3: Escherichia coli count (cfu/ml) of Naira denominations recovered from

2 different food vendors

\begin{tabular}{|c|c|c|c|c|c|c|}
\hline \multirow{2}{*}{$\begin{array}{l}\text { Currency } \\
\text { denomination }\end{array}$} & \multirow[b]{2}{*}{$\begin{array}{l}\text { Fruit } \\
\text { sellers }\end{array}$} & \multicolumn{3}{|c|}{ Food vendor type } & \multirow[b]{2}{*}{$\begin{array}{l}\text { Grain } \\
\text { sellers }\end{array}$} & \multirow[b]{2}{*}{ Mean $\times 10^{3}$} \\
\hline & & $\begin{array}{l}\text { Meat } \\
\text { sellers }\end{array}$ & $\begin{array}{l}\text { Vegetable } \\
\text { sellers }\end{array}$ & $\begin{array}{l}\text { Fish } \\
\text { sellers }\end{array}$ & & \\
\hline$\$ 1000$ & NGD & $1.2 \times 10^{2}$ & $4.0 \times 10^{2}$ & $2.5 \times 10^{2}$ & NGD & 0.15 \\
\hline$\# 500$ & $4.0 \times 10^{3}$ & $7.0 \times 10^{1}$ & $2.0 \times 10^{2}$ & $3.0 \times 10^{3}$ & $2.0 \times 10^{1}$ & 1.46 \\
\hline$\Uparrow 200$ & $9.0 \times 10^{2}$ & $6.1 \times 10^{3}$ & $6.0 \times 10^{2}$ & $5.2 \times 10^{2}$ & $1.0 \times 10^{2}$ & 1.64 \\
\hline$\# 100$ & NGD & $6.5 \times 10^{3}$ & $3.0 \times 10^{2}$ & $1.0 \times 10^{4}$ & $2.0 \times 10^{1}$ & 3.36 \\
\hline$\# 50$ & $1.2 \times 10^{3}$ & $2.0 \times 10^{3}$ & $4.0 \times 10^{2}$ & $3.2 \times 10^{3}$ & $8.0 \times 10^{2}$ & 1.52 \\
\hline$\# 20$ & NGD & $5.0 \times 10^{3}$ & $2.0 \times 10^{2}$ & $3.0 \times 10^{2}$ & NGD & 1.10 \\
\hline \#10 & $1.3 \times 10^{3}$ & $3.0 \times 10^{2}$ & $2.0 \times 10^{2}$ & $1.0 \times 10^{2}$ & $4.0 \times 10^{1}$ & 0.39 \\
\hline$\# 5$ & $7.0 \times 10^{2}$ & $2.0 \times 10^{2}$ & $2.0 \times 10^{2}$ & $1.6 \times 10^{2}$ & $2.0 \times 10^{1}$ & 0.24 \\
\hline Mean $\times 10^{3}$ & 1.01 & 2.54 & 0.31 & 2.18 & 0.12 & \\
\hline
\end{tabular}

3 Values are the means of duplicate determinations

$4 \quad$ NGD $=$ No Growth Detected 


\section{Table 4 (on next page)}

Klebsiella sp. count (cfu/ml) of Naira denominations recovered from different food vendors 
1 Table 4: Klebsiella sp. count (cfu/ml) of Naira denominations recovered from

2 different food vendors

\begin{tabular}{lllllll}
\hline $\begin{array}{l}\text { Currency } \\
\text { denomination }\end{array}$ & $\begin{array}{l}\text { Fruit } \\
\text { sellers }\end{array}$ & $\begin{array}{l}\text { Meat } \\
\text { sellers }\end{array}$ & $\begin{array}{l}\text { Vood vendor type } \\
\text { sellers }\end{array}$ & $\begin{array}{l}\text { Fish } \\
\text { sellers }\end{array}$ & $\begin{array}{l}\text { Grain } \\
\text { sellers }\end{array}$ & Mean $\times 10^{3}$ \\
\hline N1000 & NGD & NGD & $7.0 \times 10^{2}$ & NGD & NGD & 0.14 \\
$\# 500$ & $8.5 \times 10^{2}$ & $5.0 \times 10^{2}$ & $1.8 \times 10^{3}$ & $5.0 \times 10^{3}$ & $4.0 \times 10^{1}$ & 1.64 \\
$\# 200$ & $6.0 \times 10^{2}$ & $5.2 \times 10^{3}$ & $4.0 \times 10^{2}$ & $8.5 \times 10^{2}$ & NGD & 1.41 \\
\#100 & $2.7 \times 10^{3}$ & NGD & $1.4 \times 10^{2}$ & NGD & NGD & 0.57 \\
\#50 & $3.5 \times 10^{2}$ & $8.0 \times 10^{2}$ & $1.2 \times 10^{3}$ & $2.0 \times 10^{2}$ & $1.1 \times 10^{2}$ & 0.53 \\
\#20 & $7.0 \times 10^{2}$ & $3.0 \times 10^{2}$ & $5.0 \times 10^{2}$ & $1.9 \times 10^{2}$ & $4.0 \times 10^{1}$ & 0.35 \\
\#10 & $2.0 \times 10^{2}$ & $4.0 \times 10^{1}$ & $1.0 \times 10^{2}$ & $2.0 \times 10^{2}$ & $6.0 \times 10^{1}$ & 0.12 \\
\#5 & $3.2 \times 10^{2}$ & NGD & $3.0 \times 10^{2}$ & NGD & NGD & 0.12 \\
Mean $\times 10^{3}$ & 0.72 & 0.86 & 0.64 & 0.81 & 0.03 &
\end{tabular}

3 Values are the means of duplicate determinations

$4 \quad$ NGD $=$ No Growth Detected 


\section{Table 5 (on next page)}

Staphylococci sp. count (cfu/ml) of Naira denominations recovered from different food vendors 
1 Table 5: Staphylococci sp. count (cfu/ml) of Naira denominations recovered from

2 different food vendors

\begin{tabular}{lllllll}
\hline $\begin{array}{l}\text { Currency } \\
\text { denomination }\end{array}$ & $\begin{array}{l}\text { Fruit } \\
\text { sellers }\end{array}$ & $\begin{array}{l}\text { Meat } \\
\text { sellers }\end{array}$ & $\begin{array}{l}\text { Vood vendor type } \\
\text { sellers }\end{array}$ & $\begin{array}{l}\text { Fish } \\
\text { sellers }\end{array}$ & $\begin{array}{l}\text { Grain } \\
\text { sellers }\end{array}$ & Mean $\times 10^{3}$ \\
\hline \#1000 & $3.0 \times 10^{2}$ & $2.8 \times 10^{3}$ & NGD & $1.5 \times 10^{2}$ & NGD & 0.65 \\
\#50 & $3.7 \times 10^{3}$ & $1.6 \times 10^{2}$ & $7.0 \times 10^{1}$ & $4.3 \times 10^{3}$ & NGD & 1.65 \\
\#200 & $4.2 \times 10^{2}$ & $3.7 \times 10^{3}$ & $6.0 \times 10^{3}$ & $1.5 \times 10^{2}$ & $9.2 \times 10^{2}$ & 2.24 \\
\#100 & $8.0 \times 10^{2}$ & $2.7 \times 10^{3}$ & $2.0 \times 10^{2}$ & $4.0 \times 10^{3}$ & $1.6 \times 10^{3}$ & 1.86 \\
\#50 & $1.9 \times 10^{3}$ & $1.8 \times 10^{2}$ & $1.2 \times 10^{2}$ & $3.5 \times 10^{3}$ & $5.0 \times 10^{1}$ & 1.15 \\
\#20 & NGD & $4.0 \times 10^{2}$ & $1.2 \times 10^{2}$ & $6.0 \times 10^{3}$ & $4.0 \times 10^{1}$ & 1.24 \\
\#10 & $4.1 \times 10^{2}$ & $8.0 \times 10^{2}$ & $9.0 \times 10^{2}$ & $3.0 \times 10^{2}$ & $5.0 \times 10^{1}$ & 0.35 \\
\#5 & NGD & $1.1 \times 10^{2}$ & NGD & $4.0 \times 10^{2}$ & $1.4 \times 10^{2}$ & 0.13 \\
Mean $\times 10^{3}$ & 0.94 & 1.22 & 0.93 & 2.35 & 0.35 & \\
\hline Nas & & & & &
\end{tabular}

3 Values are the means of duplicate determinations

$4 \quad$ NGD $=$ No Growth Detected 


\section{Table 6(on next page)}

Prevalence of E. coli, Klebsiella sp., Staphylococci sp. on currency notes from different food vendors 
1 Table 6: Prevalence of E. coli, Klebsiella sp., Staphylococci sp. on currency notes

2 from different food vendors

\begin{tabular}{|c|c|c|c|c|c|c|}
\hline $\begin{array}{l}\text { Isolated } \\
\text { bacteria }\end{array}$ & $\begin{array}{l}\text { Fruit } \\
\text { sellers }\end{array}$ & $\begin{array}{l}\text { Meat } \\
\text { sellers }\end{array}$ & $\begin{array}{l}\text { Vegetable } \\
\text { sellers }\end{array}$ & $\begin{array}{l}\text { Fish } \\
\text { sellers }\end{array}$ & $\begin{array}{l}\text { Grain } \\
\text { sellers }\end{array}$ & Total \\
\hline E. coli & $5(62.5 \%)$ & $8(100 \%)$ & $8(100 \%)$ & $8(100 \%)$ & $6(75 \%)$ & 5 ( \\
\hline
\end{tabular}

Klebsiella sp. $7(87.5 \%) \quad 5(62.5 \%) \quad 8(100 \%) \quad 5(62.5 \%) \quad 4(50 \%) \quad 29(72.5 \%)$

Staphylococci $6(75 \%) \quad 8(100 \%) \quad 6(75 \%) \quad 8(100 \%) \quad 6(75 \%) \quad 34(85 \%)$

sp.

$\begin{array}{lllllll}\text { Total } & 18(75 \%) & 21(87.5 \%) & 22(91.7 \%) & 21(87.5 \%) & 16(66.7 \%) & 98(81.7 \%)\end{array}$

3

4

5 